\title{
EDITORIAL
}

\section{REVISTA DO CBC: NOVOS RUMOS}

\section{TCBC José Antônio Gomes de Souza}

A função de Diretor de Publicações da Revista do Colégio Brasileiro de Cirurgiões é uma tarefa árdua pois ele tem a obrigação de dar continuidade ao excelente trabalho dos que o antecederam mantendo a revista como a mais importante publicação cirúrgica do país. É necessário que seja criativo para atrair cada vez mais a atenção dos membros do CBC para os quais ela é dirigida.

$\mathrm{O}$ ano de 2000 foi de mudanças iniciadas ainda na gestão passada com uma reunião dos membros dos Conselhos Redatorial e Editorial durante o Congresso Brasileiro de Cirurgia realizado em julho de 1999 no Rio de Janeiro, cujas sugestões foram publicadas no Boletim Informativo do CBC no 105 (julho/setembro/1999), e começaram a ser implantadas ainda no ano passado com a confecção do índice remissivo elaborado pelo TCBC Aldo da Cunha Medeiros.

Foram realizadas e divulgadas modificações nas "Instruções aos Colaboradores" que passaram a seguir o Uniform Requirements for Manuscripts Submitted to Biomedical Periodical Journals elaborado pelo International Committee of Medical Journals Editors (ICMJE) conhecida como "Convenção de Vancouver" publicada no New Engl J Med, 1997, 336(4): 309-315. Entretanto, a implantação real das modificações, principalmente no que se refere à estruturação dos artigos originais, resumos e abstracts só estará se tornando possível a partir da edição no 1 de 2001 . Também na primeira edição do ano e com a divulgação deste editorial os "Artigos de Atualização" serão solicitados (encomendados) pela Diretoria de Publicações a um autor com sabida experiência no tema, que poderá ter um colaborador na elaboração do trabalho.

Outra alteração a ser comentada é a restrição do número de "Relatos de Casos" que não deverá ultrapassar a quatro por edição, com a tendência de mais redução, o que favorecerá um espaço maior para os artigos originais.

Há que se chamar a atenção para a prestimosa atuação dos membros do Conselho Redatorial que, além das suas atividades profissionais, em geral intensas, não se negam a colaborar com a Revista do CBC, emitindo pareceres do mais alto nível. Quanto aos autores, o reconhecimento pela paciência quando solicitados a elaborar as modificações exigidas de acordo com as Normas de Publicação. Não podemos deixar de elogiar o trabalho dos Redatores Secretários TCBC Guilherme Pinto Bravo Neto e Luiz Francisco Poli de Figueiredo, este na correção dos abstracts, e da Sra. Hildelita L. dos Santos na chefia do Setor de Publicações e responsável maior pela organização administrativa da revista e boletim.

Durante o ano de 2000 recebemos 124 trabalhos, tendo sido publicados 83, o que demonstra a grande procura por espaço na Revista do CBC. É claro que, apesar da efetiva contribuição do Conselho Redatorial, ainda existe uma demora no recebimento dos pareceres e na devolução das correções, o que explica o tempo entre recebimento da primeira via e a aprovação para publicação, fazendo com que no ano 2000 a maior parte dos trabalhos publicados tenha sido recebida em 1999. Esperamos que haja maior agilidade na correspondência, após a instalação da Internet no Setor de Publicações.

Tem sido solicitado ao Colégio Brasileiro de Cirurgiões a confecção de "Suplementos" e/ou a inclusão de "Cadernos" na revista, fato que levou o Diretório Nacional a estabelecer normas para que tais pedidos sejam avaliados. Estas normas encontram-se publicadas após as "Instruções aos Colaboradores".

Estamos trabalhando com afinco no sentido de conseguir a indexação da nossa revista no Index Medicus pois ela já consta do LILACS, que é restrito à América Latina.

Agradecemos não só ao TCBC Roberto Saad Júnior atual Presidente do CBC, como aos TCBCs Samir Rasslan, José Wazen da Rocha e Luiz Guilherme B. Romano, e aos demais membros do Diretório Nacional pelo apoio, estímulo e confiança demonstrados a este setor. 